\title{
PHYTOCHEMICAL STUDIES ON COTULA CINEREA L. AT DIFFERENT HABITATS
}

\author{
Abozeed, Atef E. \\ Department of Medicinal and Aromatic Plants, Desert Research \\ Center, Cairo, Egypt
}

$\mathrm{T}$ his study aimed to investigate the chemical constituents of Cotula cinerea at three different habitats (Al-Arish, Saint Catherine and Matruh) during growth season of 2008. Phytochemical screening of the aerial plant parts revealed the presence of sterols (except Saint Catherine habitat) volatile oils, tannins, saponins, flavonoids, alkaloids, carbohydrates and/or glycosides, sulphates and chlorides. Determination of constants and other constituents revealed some differences in these values between the three different habitats. The percentages of total flavonoids and saponins reached to their maximum values in the plants at Matruh habitat, while the highest values of alkaloid and tannins were detected in the plants at Al-Arish habitat. The free and combined sugars were detected by using GLC. The free amino acids were detected by using paper liquid chromatography, while the protein amino acids were detected by using the amino acid analyzer. The fundamental chemical properties of lipids of Cotula cinerea collected from the three different habitats were determined. The obtained GLC results showed that the unsaponifiable matter of the lipids contained squalene and cholesterol at the three habitats, while stigmasterol and $\beta$-sitosterol were present only in Al-Arish and Saint Catherine habitats. GLC chromatograms of the fatty acids content showed that the plants of Matruh habitat contained eleven fatty acids, while the plants of Al-Arish and Saint Catherine contained only eight fatty acids. The higher percentage was that of oleic acid in the three studied habitats.

Keywords: Compositae, Cotula cinerea, phytochemical screening, carbohydrates, amino acids, fatty acids

The studied plant belongs to family Asteraceae (Compositae), which is one of largest families of plant kingdom. It includes about 25,000 species in over 15,000 genera. This family contains large number of species some of them were used as a source of human foods and others as medicinal plants. 
The widespread use of many species of this family for medicinal purposes led to a suggestion of selecting the desert plant Cotula cinerea for careful phytochemical studies.

Ahmed et al. (1987) investigated the flavonoids of Cotula cinerea and found that the aerial parts of the plant contain kaempferitin, quercetrin, quercetin, kaempferol and some other flavonoid compounds.

The antibacterial activity of ethyl ether, ethyl acetate and n-butanol extracts of Cotula cinerea was investigated. The n-butanol extract was highly effective against pathogens at concentrations ranging from 12 to 200 $\mu \mathrm{g} / \mathrm{ml}$ (Markouk et al., 1999).

The larvicidal properties of 16 extracts of four Moroccan medicinal plants: Calotropis procera (Wild), Cotula cinerea (L.), Solanum sodomaeum (L.) and Solanum elaeagnifolium (CAV.) were tested against Anopheles labranchiae mosquito larvae. Among the extracts tested, nine exhibited high larvicidal activity with LC50 (24 h) ranging from 28 to $325 \mathrm{ppm}$ (Markouk et al., 2000).

The antipyretic activity of different extracts from Calotropis procera, Cotula cinerea and Zygophyllum gaetulum was investigated experimentally in rats. The antipyretic effect was retained in all extracts tested and was comparable to that of acetylsalicylic acid used as the standard drug (Larhsini et al., 2002).

Ethyl ether, ethyl acetate and n-butanol extracts of Cotula cinerea L. were tested for their antiprotozoal activity against two species of Trichomonas; Trichomonas intestinals and Trichomonas vaginalis. It has been found that the growth of both Trichomonas was significantly inhibited (Markouk et al., 2002).

The chemical composition and anticandidal properties of the essential oil of Moroccan Cotula cinerea aerial parts have been examined. GC-MS data were used to identify 24 constituents (El Bouzidi et al., 2011).

This study aimed to investigate the main chemical constituents of Cotula cinerea at the three different habitats to clarify the effect of environmental conditions on the main biochemical constituents.

\section{MATERIALS AND METHODS}

The plant material of Cotula cinerea $\mathrm{L}$. was collected during growth seasons of 2008 from three natural locations; Al-Arish, Saint Catherine and the road of Alexandaria- Marsa Matruh. The collected plants were cleaned, dried in an oven at $60^{\circ} \mathrm{C}$ for 48 hours, ground to fine powder and presented for the chemical investigation.

Egyptian J. Desert Res., 62/63, 39-54 (2012/2013) 


\section{Preliminary Phytochemical Screening}

\subsection{Steam distillation}

About $5 \mathrm{~g}$ of fresh plant material were subjected to steam distillation according to British Pharmacopeia (1980) method for volatile oil content.

\subsection{Screening of the active principles}

About $50 \mathrm{~g}$ of air dried powdered plant material were refluxed with about $50 \mathrm{ml}$ of $80 \%$ ethyl alcohol for 6 hours, then filtered. The residue powder was then washed several times with hot alcohol. The combined alcohol filtrates were concentrated under reduced pressure at $50^{\circ} \mathrm{C}$, then used for the following tests:

- Test for tannins: According to Balbaa (1986).

- Test for sterols and terpens: According to Balbaa et al. (1981).

- Test for flavonoids: According to Wall et al. (1954).

- Test for alkaloids: According to Woo et al. (1977).

- Test for carbohydrates and/or glycosides: According to Harper (1975).

- Test for saponins: According to Balbaa (1986).

- Test for chlorides and sulphates: According to A.O.A.C. (1970).

\section{Determination of Constants and Other Constituents}

Water content was estimated according to the method described by Rowell (1994), the total soluble and insoluble carbohydrates were determined according to Chaplin and Kennedy (1994). The total nitrogen and protein contents were determined according to James (1995) and the total lipids were determined according to Christie (1982). The total ash content, acid and water insoluble ash and the crude fiber contents were determined according to Askar and Treptow (1993).

\section{Determination of Active Constituents}

\subsection{Determination of total flavonoids}

The total flavonoids were determined spectrophotometerically as described by Karawya and Aboutable (1982).

\subsection{Determination of total alkaloids}

The total alkaloids were estimated using two methods, the acid- base titration and the gravimeteric methods as described by Balbaa (1986) and Woo et al. (1977).

\subsection{Determination of total saponin}

Saponin content of the studied plants was determined according to Balbaa (1986).

\subsection{Determination of total tannins}

The total tannins were estimated according to the method of Makkar and Googchild (1996). 


\section{Investigation of Carbohydrates}

The free sugars were extracted from the defatted powder of Cotula cinerea by pyridine (Malpress and Morrison, 1949), cooled filtered and evaporated under vacuum at $45-50^{\circ} \mathrm{C}$. The residue was dissolved in $10 \mathrm{ml}$ of $10 \%$ isopropyl alcohol and subjected to gas-liquid chromatographic (GLC) technique (Eaton, 1989). The combined sugars were hydrolyzed after extraction with redistillation with $6 \mathrm{~N} \mathrm{HCl}$ and subjected to GLC technique.

\section{Investigation of Free and Protein Amino Acids}

The free amino acids were prepared according to Patton and Chism (1951) and separated using Whatman no. 1 filter paper chromatography. The solvents used were n-butanol: acetic acid: water (4:1:5) (Smith and Seakins, 1976) and ninhydrine $(0.25 \%)$ as coloured reagent, which was prepared according to Block et al. (1958).

The hydrolyzed protein amino acids determined using amino acid analyzer according to the method described by Pellet and Young (1980).

\section{Investigation of Lipids}

The lipids were extracted from the powdered plant with petroleum ether (B.P. $\left.40-60^{\circ} \mathrm{C}\right)$ : ether $(1: 1 \mathrm{v} / \mathrm{v})$ for 24 hours using soxhlet apparatus. The lipids were obtained by distilling off the solvent. The last traces of the solvents were removed by heating the liquid sample in vacuum oven a $50^{\circ} \mathrm{C}$ to constant weight.

\subsection{The fundamental chemical properties}

Acid value (A.V.), iodine value (I.V.), ester value (E.V.) and saponification value (S.V.) were determined according Mohamed and Amer (1965).

\subsection{Investigation of fatty acids and unsaponifiable matter}

The extracted lipids of Cotula cinerea were saponified and purified according to British Pharmacopoeia (1980). The unsaponifiable fraction was removed from the soapy solution by shaken in a separating funnel for several times with fresh portions of peroxide-free ether until complete extraction was obtained.

The soapy solution was converted into the corresponding free fatty acids by using of $2.5 \%$ sulphuric acid. When the acid was completely liberated, they were collected by ether extraction. The ether extracted was washed several times with distilled water until free from acids, dried over anhydrous $\mathrm{Na}_{2} \mathrm{SO}_{4}$, then filtered and the ether was removed by distillation. The last traces of ether were removed under vacuum at $60^{\circ} \mathrm{C}$, and then cooled in a desiccator.

\subsection{GIC of fatty acids}

The extracted fatty acids and the standard ones were converted to the corresponding methyl esters using ethereal solution of diazomethane (Farag 
et al., 1986). The methyl ester of the fatty acids was analyzed with a GCV. Pye-Unicam gas chromatography apparatus. The fraction of fatty acid methyl esters were conducted using a coiled glass column $(150 \mathrm{~mm}, 4 \mathrm{~mm})$, packed with diatomite $\mathrm{C}(100-120$ mesh) and coated with $10 \%$ polyethylene glycol.

The column oven temperature was programmed at $10^{\circ} \mathrm{C} /$ minute for 100 and $200^{\circ} \mathrm{C}$, then isothermally at $200^{\circ} \mathrm{C}$ for 15 minutes with nitrogen at $30 \mathrm{ml} /$ minutes. Peak identification was performed by comparing the relative retention time of each compound with those of standard material. The relative proportion of each individual compound were estimated as the ratio of the partial areas of the total area as mentioned by Fryer et al. (1960), Nelson et al. (1969), Farag et al. (1986) and Khalil (1987).

\subsection{GLC of unsaponifiable matter}

The relative percentage of each unsaponifiable compound was determined using triangulation method according to Nelson et al. (1969). The results of Itoh et al. (1973) and Farag et al. (1986) were used as aguide to characterize some of the unknown compounds.

\section{RESULTS AND DISCUSSION}

\section{Preliminary Phytochemical Screening}

The preliminary phytochemical screening of Cotula cinerea L. showed that it contained sterols, except for Saint Catherine plants, volatile oil, flavonoids, tannins, saponins, chlorides, sulphates, carbohydrates and/or glycosides and alkaloids (Table 1).

Table (1). Preliminary phytochemical screening of Cotula cinerea.

\begin{tabular}{lc}
\hline Test & Result \\
\hline Volatile oil & + \\
Sterols & + \\
& except Saint Catherine plant \\
Tannins & + \\
Flavonoids & + \\
Alkaloids & + \\
Carbohydrates & + \\
and/or & \\
glycosides & \\
Saponins & + \\
Sulphates & + \\
and chlorides & \\
\hline
\end{tabular}

\section{Determination of Constants and Other Constituents}

It is clear from table (2) that the mean values of water content, ash content, water-soluble ash, soluble carbohydrates, insoluble carbohydrates 
and total carbohydrate content were higher in the plants of Cotula cinerea at Al-Arish habitat than the other two habitats, while the acid-insoluble ash, total nitrogen, total protein and the crude fiber contents reached to their maximum values in the plants of Cotula cinerea $\mathrm{L}$. at Matruh habitat.

\section{Determination of the Active Constituents}

The natural plants produce different kinds of natural secondary metabolities during their metabolism, where the natural/secondary compounds vary according to environmental conditions. Some of these compounds have an essential role in growth and development but the majority of them are involved in chemical defense systems, which protect plants from herbivores and microbial infection (Michael, 1997). Data indicated that the percentages of total flavonoids were 1.64, 1.48 and 2.02\% at Al-Arish, Saint Catherin and Matruh, respectively. Data also indicated that the percentage of total alkaloids at Al-Arish $(0.34 \%)$ was higher than the other two habitats. It is well known that the amount of alkaloids in plants is small, so the differences appear as a very small amount. Alkaloids are poisonous agents protecting the plant against insects and herbivores, so during growth and development of plants, alkaloids are used as defensive agents and concentrate, near the surface regulatory growth factors and they are capable of supplying nitrogen or other elements to the plants (Balbaa, 1986).

Table (2). Mean values of constants and constituents of Cotula cinerea in different habitats.

\begin{tabular}{lccc}
\hline $\begin{array}{l}\text { Constants and } \\
\text { constituents }\end{array}$ & \multicolumn{3}{c}{ Habitat } \\
\cline { 2 - 4 } & Al-Arish & $\begin{array}{c}\text { Saint } \\
\text { Catherine }\end{array}$ & Matruh \\
\hline $\begin{array}{l}\text { Moisture content (\%) } \\
\text { Ash content (\%) }\end{array}$ & 12.08 & 10.56 & 11.80 \\
Water-soluble ash (\%) & 13.20 & 12.76 & 10.46 \\
Acid-insoluble ash (\%) & 4.60 & 3.58 & 3.94 \\
Total nitrogen (mg/g) & 2.36 & 2.02 & 3.64 \\
Total protein (mg/g) & 0.68 & 0.86 & 0.92 \\
Total lipid content (\%) & 4.24 & 5.23 & 5.73 \\
Soluble carbohydrates & 1.77 & 1.80 & 2.03 \\
(mg/g) & 2.03 & 1.16 & 1.96 \\
Insoluble carbohydrates & 0.94 & 0.83 & 0.88 \\
(mg/g) & & & \\
Total carbohydrates (mg/g) & 2.97 & 1.99 & 2.84 \\
Crude fiber content (\%) & 18.22 & 16.75 & 24.80 \\
\hline
\end{tabular}

Egyptian J. Desert Res., 62/63, 39-54 (2012/2013) 
Table (3). Percentages of total flavonoids, alkaloids, tannins and saponins at different habitats.

\begin{tabular}{lccc}
\hline Compounds & \multicolumn{3}{c}{ Habitat } \\
\cline { 2 - 4 } & Al-Arish & Saint Catherine & Matruh \\
\hline Total flavonoids & 1.64 & 1.48 & 2.02 \\
Total alkaloids & 0.34 & 0.26 & 0.28 \\
Total tannins & 2.43 & 1.67 & 2.24 \\
Total saponins & 7.63 & 6.64 & 9.33 \\
\hline
\end{tabular}

Tannins high concentration was detected at Al-Arish habitat. Tannins inhibit the growth of many fungi (Balbaa, 1986) and play a role in protecting the plant against grazing animals as they cause increase of the excretion of salvia and thus decrease the palatability and rate of digestion in animals (Michael, 1997). The total saponins at the three habitats was illustrated in table (4). Data indicated that the percentages of total saponins of Cotula cinerea L. were 7.63, 6.64 and $9.33 \%$ at Al-Arish, Saint Catherine and Matruh, respectively. Saponins are toxic to animals, so accumulation of them in plants are defensive against herbivore, especially on the surface (Balbaa, 1986).

\section{Investigation of Carbohydrates}

The obtained GLC chromatograms of free sugars of Cotula cinerea L. show the presence of ribose, arabinose, glucose and maltose in the three studied habitats, beside galactose in Al-Arish and Saint Catherine habitats, raffinose in Al-Arish and Matruh habitats, beside some unknown sugars as free sugars (Table 4).

Table (4). Free sugar percentages of Cotula cinerea at different habitats.

\begin{tabular}{lccc}
\hline Sugar & \multicolumn{3}{c}{ Relative percentages (\%) } \\
\cline { 2 - 4 } & Al-Arish & Saint Catherine & Matruh \\
\hline Unknown & 1.54 & - & 2.07 \\
Ribose & 6.42 & 6.80 & 5.96 \\
Arabinose & 3.84 & 5.56 & 4.08 \\
Galactose & 3.21 & 2.15 & - \\
Glucose & 8.84 & 3.98 & 10.08 \\
Maltose & 9.21 & 7.65 & 8.12 \\
Raffinose & 16.24 & - & 19.00 \\
\hline
\end{tabular}

GLC chromatograms of combined sugars of Cotula cinerea of the three studied habitats revealed the presence of ribose, arabinose, sorbose, galactose, glucose and maltose in Al-Arish, Saint Catherine and Matruh habitats. Meanwhile, rhamnose was detected only at Saint Catherine and 
Matruh habitats, beside some unknown sugars as combined sugar in the plant (Table 5).

Table (5). Combined sugar percentages in Cotula cinerea at different habitats.

\begin{tabular}{lccc}
\hline \multirow{2}{*}{ Sugar } & \multicolumn{3}{c}{ Relative percentages (\%) } \\
\cline { 2 - 4 } & Al-Arish & Saint Catherine & Matruh \\
\hline Rhamnose & - & 9.75 & 6.22 \\
Ribose & 3.09 & 4.66 & 5.32 \\
Unknown & - & 3.33 & - \\
Arabinose & 4.37 & 2.78 & 3.29 \\
Sorbose & 12.72 & 13.92 & 15.06 \\
Galactose & 3.26 & 7.02 & 9.51 \\
Glucose & 6.91 & 5.23 & 5.21 \\
Maltose & 4.43 & 4.05 & 5.62 \\
Unknown & - & - & 3.41 \\
\hline
\end{tabular}

\section{Investigation of Free and Protein Amino Acids}

\subsection{Free amino acids}

The free amino acids of Cotula cinerea at the three studied areas are presented in table (6). It is obvious from table (6) the presence of therionine, aspartic acid, glutamic acid, proline and methionine in the plants of the three habitats, alanine and glycine in Saint Catherine and Matruh and leucine was present only at Al-Arish plants.

Table (6). The presence of free amino acids in Cotula cinerea at the three studied areas.

\begin{tabular}{lccc}
\hline Free amino acid & \multicolumn{3}{c}{ Locality } \\
\cline { 2 - 4 } & Al-Arish & Saint Catherine & Matruh \\
\hline Therionine & + & + & + \\
Aspartic acid & + & + & + \\
Alanine & - & + & + \\
Glutamic acid & + & + & + \\
Proline & + & + & + \\
Glycine & - & + & + \\
Methionine & + & - & + \\
Leucine & + & & - \\
\hline
\end{tabular}

\subsection{Protein amino acids}

The investigation of hydrolyzed protein amino acids of Cotula cinerea at the three studied areas was achieved using amino acid analyzer. The data presented in table (7) show that the plants contained seventeen amino acids with different ranges of concentrations and the maximum 
amount of total acids was presented in Matruh and the minimum at Al-Arish habitat.

The clear variation in amino acid contents between habitats may be due to the severe environmental conditions of the desert. High ratios of soluble and insoluble proteins may be due to increased proteolic activity for osmoregulation (Cusido et al., 1987).

Ali (1991) found that the contents of proline in both shoots and roots of Trigonella foenum gracecum L. increased progressively with the rise of salinization level. These results are in accordance with those obtained by some other authors (Stewart and Larher, 1980; Ahmed et al., 1989 and Foda et al., 1997).

Ali and Sawaf (1992) reported that salinity could inhibit the transmination reactions and hence glutamic acid is accumulated and transformed to other nitrogenous compounds such as proline.

Table (7). Protein amino acids of Cotula cinerea using amino acid analyzer ( $\mathrm{g} / 100 \mathrm{~g}$ dry weight).

\begin{tabular}{lccc}
\hline Amino acid & \multicolumn{3}{c}{ Habitats } \\
\cline { 2 - 4 } & Al-Arish & $\begin{array}{c}\text { Saint } \\
\text { Catherine }\end{array}$ & Matruh \\
\hline Aspartic acid & 0.49 & 0.28 & 0.50 \\
Therionine & 0.34 & 0.35 & 0.41 \\
Serine & 0.23 & 0.17 & 0.28 \\
Glutamic acid & 0.57 & 0.62 & 0.66 \\
Proline & 0.61 & 0.50 & 0.68 \\
Glycine & 0.16 & 0.28 & 0.29 \\
Alanine & 0.09 & 0.42 & 0.47 \\
Cysteine & 0.18 & 0.19 & 0.27 \\
Valine & 0.26 & 0.32 & 0.38 \\
Methionine & 0.12 & 0.18 & 0.22 \\
Isoleucine & 0.19 & 0.17 & 0.20 \\
Leucine & 0.28 & 0.12 & - \\
Tyrosine & 0.12 & 0.18 & 0.21 \\
Phenylalanine & 0.20 & 0.43 & 0.46 \\
Histidine & 0.13 & 0.18 & 0.23 \\
Lysine & 0.22 & 0.26 & 0.28 \\
Arginine & 0.17 & 0.21 & 0.29 \\
\hline
\end{tabular}

\section{Investigation of Lipids}

\subsection{Physical properties of lipids}

The obtained lipids were dark green in colour at Al-Arish and Saint Catherine, while they were yellowish green in colour at Matruh, semi-solid having a faint odour. They were soluble in n-hexane, ether, petroleum ether, chloroform, acetone, benzene, warm methyl and ethyl alcohol. 


\subsection{Fundamental chemical properties}

The fundamental chemical properties of the extracted lipids of Cotula cinerea collected from the three habitats are presented in table (8). It is clear from the data obtained that acid, iodine, ester and saponification values were higher at Saint Catherine than the other two habitats.

Table (8). Acid, iodine, ester and saponification values of Cotula cinerea at the three habitats.

\begin{tabular}{lccc}
\hline Items (mg\%) & \multicolumn{3}{c}{ Habitats } \\
\cline { 2 - 4 } & Al-Arish & Saint Catherine & Matruh \\
\hline Acid value & 38.30 & 46.28 & 40.26 \\
Iodine value & 80.21 & 87.19 & 79.18 \\
Ester value & 140.98 & 152.23 & 146.20 \\
Saponification & 189.20 & 198.51 & 186.46 \\
value & & & \\
\hline
\end{tabular}

\subsection{Unsaponifiable matter contents}

The unsaponifiable matter of Cotula cinerea at the three different habitats was determined using GLC technique. The relative percentages of each component were calculated and tabulated in table (9), which revealed the presence of dodecane, octadecane, eicosane, hencosane, docosane, tricosane, tetracosane and squalene in the plants of the three habitats, while pentacosane was present only at Al-Arish. Hexacosane was present only at Al-Arish and Matruh habitats. Meanwhile triacontane was present only at Al-Arish and Saint Catherine plants. With regard to sterols, it revealed the presence of cholesterol in the plants of the three habitats, while stigmasterol and $\beta$-sitosterol were present only at Al-Arish and Saint Catherine. The wide distribution of cholesterol in plants has been relatively shown by Trease and Evans (1983).

\subsection{The saponifiable fraction (free fatty acids)}

The saponifiable contents of Cotula cinerea at the three different habitats were determined using GLC technique. The relative percentage of each component was calculated and tabulated in table (10). It is obvious that the unsaturated fatty acids $(18.31 \%)$ in the plants of Al-Arish habitat and the lowest one was the saturated fatty acid (myristic acid) with percentage of $0.44 \%$ at Saint Catherine habitat. Goss (1973) stated that the most abundand fatty acids of desert plants were palmitic, stearic and linoleic acids. 
Table (9). Data on hydrocarbons and sterols of Cotula cinerea at different habitats.

\begin{tabular}{lcccc}
\hline Hydrocarbon & No. of & \multicolumn{3}{c}{ Habitats } \\
\cline { 3 - 5 } and sterol & carbon & Atom & Al- & Saint \\
Catherine & Matruh \\
\hline Dodecane & $\mathrm{C}_{12}$ & 1.52 & 1.03 & 1.97 \\
Unknown & - & - & - & 2.03 \\
Octadecane & $\mathrm{C}_{18}$ & 1.03 & 2.15 & 1.97 \\
Eicosane & $\mathrm{C}_{20}$ & 4.20 & 4.10 & 5.55 \\
Hencosane & $\mathrm{C}_{21}$ & 1.12 & 1.06 & 1.34 \\
Docosane & $\mathrm{C}_{22}$ & 3.76 & 3.36 & 3.81 \\
Tricosane & $\mathrm{C}_{23}$ & 3.96 & 2.04 & 2.76 \\
Tetracosane & $\mathrm{C}_{24}$ & 2.78 & 4.06 & 1.34 \\
Pentacosane & $\mathrm{C}_{25}$ & 0.97 & - & - \\
Hexacosane & $\mathrm{C}_{26}$ & 4.22 & - & 3.72 \\
Octacosane & $\mathrm{C}_{28}$ & - & 2.49 & - \\
Squalene & - & 12.86 & 20.61 & 12.08 \\
Unknown & - & - & - & 2.42 \\
Unknown & - & - & - & 3.91 \\
Unknown & - & 2.60 & - & - \\
Triacontane & $\mathrm{C}_{30}$ & 10.06 & 2.88 & - \\
Dotriacontane & $\mathrm{C}_{32}$ & 5.27 & 3.49 & 12.04 \\
Cholesterol & - & 4.91 & 9.08 & 7.13 \\
Stigmasterol & - & 2.73 & 5.82 & - \\
$\beta$-sitosterol & - & 1.42 & 0.99 & - \\
\hline
\end{tabular}

Table (10). Fatty acids content of Cotula cinerea using GLC technique.

\begin{tabular}{lcccc}
\hline Fatty acids & $\begin{array}{c}\text { No. of } \\
\text { carbon } \\
\text { atom }\end{array}$ & Al-Arish & $\begin{array}{c}\text { Saint } \\
\text { Catherine }\end{array}$ & Matruh \\
\hline Caproic & 6.0 & - & - & 0.68 \\
Caprylic & 8.0 & - & - & 0.46 \\
Capric & 10.0 & 1.97 & 2.31 & 2.62 \\
Unknown & - & - & - & 0.29 \\
Lauric & 12.0 & 3.20 & 2.91 & 3.63 \\
Myristic & 14.0 & 1.02 & 0.44 & 0.82 \\
Palmitic & 16.0 & 2.58 & 1.46 & 3.01 \\
Stearic & 18.0 & 2.39 & 2.08 & 2.31 \\
Oleic & 18.1 & 18.31 & 13.21 & 15.63 \\
Linoleic & 18.2 & 8.01 & 5.97 & 8.86 \\
Arachidic & 20.0 & 3.35 & 4.33 & 4.93 \\
Unknown & - & - & 0.97 & - \\
Unknown & - & - & 0.86 & 0.91 \\
\hline
\end{tabular}


The previous obtained results concluded that Matruh habitat is a more favorable for spread and flourishment of Cotula cinerea than the other two habitats

\section{CONCLUSION}

The results revealed marked qualitative and quantitative differences in the chemical constituents of the plants of the three habitats. It was concluded that Matruh region is the most favorable habitat for spread and flourishment of Cotula cinerea than the other two habitats.

\section{REFERENCES}

Ahmed, A.A., N.H. El Sayed, S.I. El Negoumy and T.J. Mabry (1987). Flavonoids of Cotula cinerea. Journal of Natural Products, 5:519-520.

Ahmed, A.M., M.M. Heikal and R.M. Ali (1989). Changes in amino acid and alkaloids content in Hyoscyamus muticus and Datura stramonium in response to salinization. Phyton., 29:137-147.

Ali, R.M. (1991). Effect of salinity and maintaining a constant Na: Ca ratio, on growth and some metabolic activities of Trigonella foenum graecum L. Bull. Fac. Sci., Assiut Univ.

Ali, R.M. and N.A. Sawaf (1992). Effect of salinity alone and in combination with adipic acid or methylamine on free amino acid and alkaloids content of Datura innoxia. Journal of the Faculty of Education, Ain Shams Univ., 17:345-353.

A.O.A.C. (Association of Official Agricultural Chemists) (1970). In "Official Methods of Analysis". 11 ${ }^{\text {th }}$ ed. The A.O.A.C., Washington D.C., U.S.A.

Askar, A. and H. Treptow (1993). In "Quality Assurance". Springer-Verlag Berlin Heidlberg, Printed in Germany, 238 pp.

Balbaa, S.I. (1986). In "Chemistry of Crude Drugs Laboratory Manual". Faculty of Pharmacy, Cairo Univ., Egypt, 195 pp.

Balbaa, S.I., S.H. Hilal and A.Y. Zaki (1981). In "Medicinal Plant Constituents". $3^{\text {rd }}$ ed. General Organization for Univ. Books, Cairo, Egypt. 644 pp.

Block, R.J., E.L. Durrum and G. Sweig (1958). In "A manual of Paper Chromatography and Paper Electriphoresis". $2^{\text {nd }} e d$. Academic Press. Inc. New York, 484 pp.

British Pharmacopoeia (B.P.) (1980). Volume II: Published on the Recombination of the Medicinal Commission. Printed in England for Majesty's Stationary Office at the University Press, Cambridge, UK, 561 pp.

Egyptian J. Desert Res., 62/63, 39-54 (2012/2013) 
Chaplin, M.F and J.F. Kennedy (1994). In "Carbohydrate Analysis: A Practical Approach". Published in the United States by Oxford University Press, p. 31-32.

Christie, W.W. (1982). In "Lipid Analysis". $2^{\text {nd }}$ ed. Pergamon Press, 207 pp.

Cusido, R.M., J. Palazon, T. Altabella and C. Morales (1987). Effect of salinity on soluble protein, free amino acids and nicotine contents in Nicotiana rustica L. Plant and Soil, 102:55-60.

Eaton, D.C. (1989). In "Laboratory Investigation in Organic Chemistry". Mc-Graw-Hill Book Co., New York, St. Louis, Mexico, Mountreal, New Delhi, 929 pp.

El Bouzidi, L., A. Abbad, K. Fattarsi, L. Hassani, D. Leach, M. Markouk, L. Legendre and K. Bekkouche (2011). Chemical composition and anticandidal properties of the essential oil isolated from aerial from aerial parts of Cotula cinerea: a rare and threatened medicinal plant in Morocco. Natural Product Communications, 6(10):1491-4.

Farag, R.S., A.C. Ahmed, S.E. Rashed and M.A. Ewies (1986). Unsaponifiable matter of six pollens collected by honeybees in Egypt. J. Agric. Res., 19(4):52-58.

Foda, H.A., I.A.M. Tolba, A.K. Youssef and S.M.M. Morsi (1997). Ecological and eco-physiological studies on Sea lavender Limonium pruinosum L. var. hirtiflora. Bull. of Desert Inst. (In press).

Fryer, F.H., W.L. Ormand and G.M. Crimp (1960). Triglyceride elution by gas chromatography. A.O.C.S., 37:589-590.

Goss, J.A. (1973). In "Physiology of Plants and Their Cells". Pergaman Press Inc. New York.

Harper, H.A. (1975). In "Review of Physiological Chemistry". $15^{\text {th }}$ ed. Long Medicinal Publication, Los Angles, California, 570 pp.

Itoh, T., T. Tamura and T. Matsumoto (1973). Sterol composition of 19 vegetable oils. JAOCS, 50:12-125.

James, C.S. (1995). In "Analytical Chemistry of Foods". Blackie Academic and Professional Publisher, An Imperin of Chapman and Hall, $178 \mathrm{pp}$.

Karawya, M.S. and E.A. Aboutable (1982). Phytoconstituents of Tabernaemontana cormaria Jac. Q. Willed and Dichotoma roxii B. growing in Egypt. Partive: the flavonoid. Bulletin of Faculty of Pharma, Cairp Univ., 21(1):41-49.

Khalil, M.F. (1987). Evaluation of butter fat and virgin oil quality and integrity. Ph.D. Thesis, Fac. Agric., Cairo Univ.

Larhsini, M., M. Markouk, J.T. Jaouhari, K. Bekkouche, H.B. LazREK and M. Jana (2002). The antipyretic activity of some Morroccan medicinal plants. Phytother. Res., 16(1): S97-8. 
Makkar, H.P.S and A.V. Googchild (1996). Quantification of Tannins: A laboratory Manual. International Center Agricultural Research in the Dry Areas, Aleppo, Syria. Vol. 4, 25 pp.

Malpress, F.H. and Morrison, A.B. (1949). Use of pyridine in the deionization of solutions for paper chromatography. Nature, 164:963.

Markouk, M., A. Redwone, H.B. Lazrek, M. Jana and A. Benjama (1999). In "Antibacterial of Cotula cinerea Extracts". Department of Biology, Laboratory of Phytochemistry, Faculty of SciencesSemlalia, P.O. Box 2390, Marrakesh 4000, Morocco.

Markouk, M., B. Bekko, K. Anuche, M. Larhsini, M. Bousaid, H.B. Lazrek and M. Jana (2000). In "Evaluation of Some Moroccan Medicinal Plant Extracts for Larvicidal Activity". Laboratory of Medicinal Plants and Phytochemistry, Department of Biology, Faculty of Sciences-Semlalia, P.O. Box 2390 Marrakesh 4000, Morocco.

Markouk, M., H.B. Lazrek, M. Larhsini, K. Bekkouche and M. Jana (2002). Preliminary screening of antiprotozoal activity of extracts from Cotula cinerea L. Therapie, 54:759-61.

Michael, J.C. (1997). In "Plant Ecology". Black Iven Science LTD, Maldden. USA, p. 132-155.

Mohamed, F.E. and M.A. Amer (1965). In "Oils, Fat, Waxes and Surfactants". Anglo. Egyptian Book Shop Publishers, Cairo, U.A.R., $259 \mathrm{pp}$.

Nelson, J.P., A.J. Milim and H.D. Fister (1969). Gas chromatographic determination of tocopherols and sterols in soya sludge's and residues an improved method. JAOCS, 47: 259-261.

Patton, A.R. and P. Chism (1951). Chromatography of amino acids. Annal Chem., 23: 1683-1685.

Pellet, P.L. and V.R. Young (1980). In "Nutritional Evaluation of Protein Foods". Published by the United Nation Univ.

Rowell, D.1. (1994). In "Soil Science-Methods and Application". Longman Publishers, Singapore, $350 \mathrm{pp}$.

Smith, I. and J. Seakins (1976). In "Chromatographic and Electrophoretic Techniques". Vol. 1, $4^{\text {th }}$ ed. William Heinemann Medicinal Books LTD, London, 465 pp.

Stewart, C.R. and F. Larher (1980). In "Accumulation of Amino Acids and Related Compounds in Relation to Environmental Stress". The Biochemistry of Plants, A comprehensive Treaties (Stumpe P.R. and E.E. Conn, eds.), Acadimic Press, New York, 5:609695.

Trease, G.E. and W.C. Evans (1983). In "Pharmacognosy". 12 $2^{\text {th }}$ ed. Alden Press, Oxford, p. 192-193. 
Wall, N.F., M.M. Kreider, C.F. Kremson, C.R. Eddy, J.J. Williaman, D.S. Corell and H.S. Gentry (1954). Steroidal sapognins and other constituents. J. Pharm. Soc., 43:1-3.

Woo, W.S., H.J. Chi and H.S. Yun (1977). Alkaloid screening of some Saudi Arabian plants Kort. J. Pharmacognosy, 8(3):109-113. 


\section{دراسات فيتوكيميائية على نبات الربيان في بيئاته المختلفة}

\section{عاطف السيد أبو زيد}

مركز بحوث الصحر اءو، المطرية، القاهرة، مصر

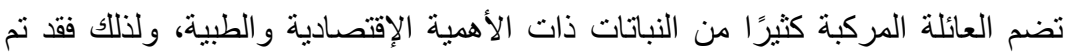

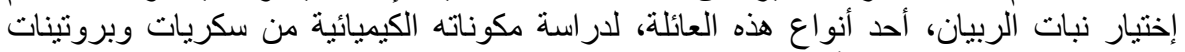

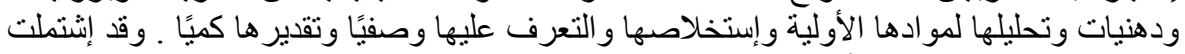

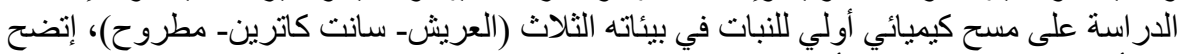

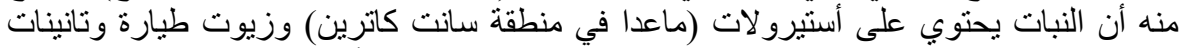

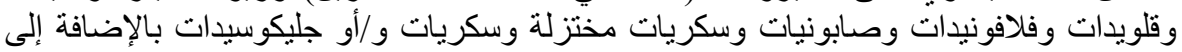
الكبريتات و الكلوريدات. وقد تم من خلال الدر اسة التي أجريت على نبات نباتات جمعت من ثلاث بيكات بئات

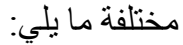

اـ تم تقدير بعض الثوابت والمكونات الكيميائية للنبات فى بيئاته الثلاث (المحتوى المائي- التئي

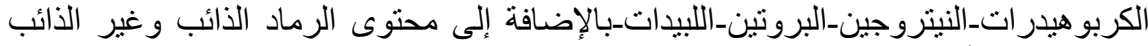

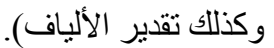

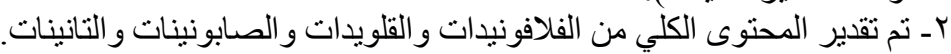
rـ التعرف على على السكريات الحرة و المرتبطة في النبات في البيئات الثلاثلاث وصفيًا وكميًا بإستعمال طرق التحليل الكروماتوجر افي الغازي. الأني.

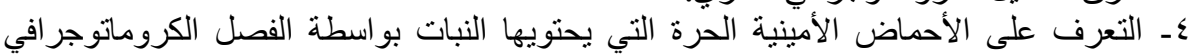

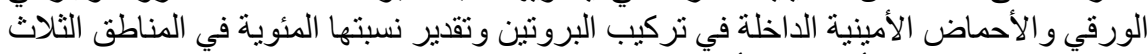
بإستخدام جهاز تحليل الأحماض الأمينية.

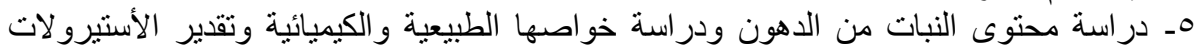

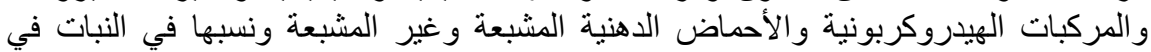

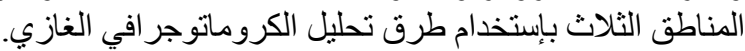

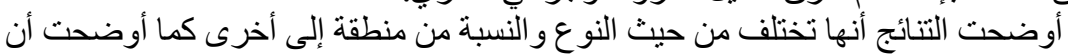

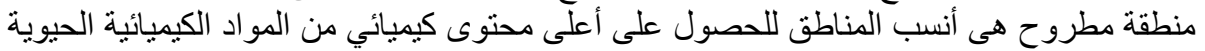

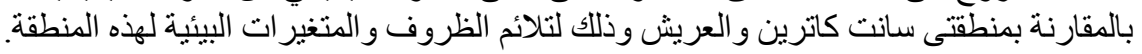

Egyptian J. Desert Res., 62/63, 39-54 (2012/2013) 
